\title{
Prevalence of Asthma in Rural Indian Children
}

2002; 69: 237-244.

19. Schenker MB, Samet JM, Speizer FE. Risk factors for childhood respiratory disease: The effect of host factors and home environmental exposures. Am Rev Respir Dis 1983; 128: $1038-1043$.

20. Viswanathan R. The Problem of asthma. Indian J Chest Dis 1972; 14: 272-288.

21. Karunaeskara KA, Jayasinghe JA, Alwis LW. Risk factors of childhood asthma: A Sri Lankan Study. J Trop Pediatr 2001; 47: 142 - 145 .

22. Verity CM, Vanheule B, Carswell F, Hughes AO. Bronchial lability and skin reactivity in siblings of asthmatic children. Arch Dis Child 1984; 59: 871-876.

23. Al-Dawood KM. Epidemiology of bronchial asthma among school boys in Al- Khobar city, Saudi Arabia. Saudi Med J 2001; 22: 61-66.

24. Ratageri VH, Kabra SK, Dwivedi SN, Seth V. Factors associated with severe asthma. Indian Pediatr 2000; 37: 1072-1082.

25. Hijazi N, Abalkhail B, Seaton A. Asthma and respiratory symptoms in urban and rural Saudi Arabia. Eur Respir J $1998 ; 12: 41-44$

\section{ERRATUM}

The article entitled "Familial Small Supernumerary Marker Chromosome (sSMC) (14) (: $\mathrm{p}^{11}-\mathrm{q}^{11}:$ ) in a Child with Translocation Down Syndrome" authored by Babu Rao Vundinti, Seema Korgoankar and Kanjaksha Ghosh, Published in December 2009 issue. Page no. 1265-1267. The title should read as "Familial Small Supernumerary Marker Chromosome (sSMC) (14) (:p11-q11:) in a Child with Translocation Down Syndrome"

The error is regretted. 